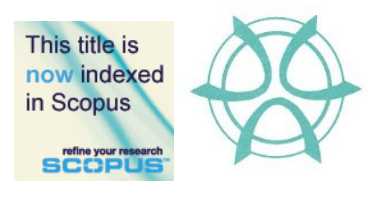

PLANNING MALAYSIA:

Journal of the Malaysian Institute of Planners

VOLUME 18 ISSUE 2 (2020), Page 158 - 169

\title{
READAPTATION OF MALAY VERNACULAR ARCHITECTURE FOR INDOOR THERMAL COMFORT IN MODERN MASJIDS TOWARDS A SUSTAINABLE DESIGN.
}

\author{
Siti Salwana Bt. Mohd Nawayai ${ }^{1}$, Zuraini Bt Denan ${ }^{2} \&$ Noor Hanita Bt \\ Abdul Majid ${ }^{3}$ \\ ${ }^{123}$ Faculty of Architecture and Environmental Design \\ INTERNATIONAL ISLAMIC UNIVERSITY MALAYSIA
}

\begin{abstract}
The earlier masjid architectural styles were similar to Malay vernacular houses and evolved with the introduction of the modernist style. This resulted in increased energy consumption. Hence, a proper set of thermal comfort is important to provide a suitable environment for the masjid's occupants. The vernacular characteristics in the passive designs have caused designers to find solutions towards sustainable designs. Therefore, designing a good thermal performance building can be done by readapting the Malay vernacular architecture and passive design strategies for modern masjids. This paper is aimed to document the literature and potential case studies in identifying the relationship between the design of Malay vernacular and thermal comfort elements in a hot and humid climate. The outcome is to formularize requirements of thermal comfort in Malay vernacular masjids based on four major factors namely i) architectural qualities, ii) construction systems, iii) structural components and iv) non-structural components. The research is intended to change the approach of future designers to become more sustainable based on the application of passive designs that suit the climatic condition of Malaysia.
\end{abstract}

Keywords: Heritage, Façade design, Thermal performance, Ventilation

\footnotetext{
${ }^{1}$ Postgraduate Student at International Islamic University Malaysia. Email: wana_9199@yahoo.com
} 
PLANNING MALAYSIA

Journal of the Malaysia Institute of Planners (2020)

\section{INTRODUCTION}

The main objective of this paper is to identify relationship between the design of Malay vernacular building components to the local climate condition. This process of identifying the relationship is important to understand the implementation of passive designs in a hot and humid climate as well as highlighting the significance of the thermal performance study in modern masjids that apply the Malay vernacular concept.

Baharudin (2016) revealed that during the 15th century, the masjid architectural style and its construction materials were similar to local traditional Malay houses. In the 19th century, masjid architecture in Malaya had changed and was influenced by the British colonial style. Moreover, in the early 20th century, the masjid architectural style was further diversified with the introduction of the modernist style. When the masjids modernize, nations and communities attempt its construction with modern materials resulting in a compromise to the passive impact of controlling climate. This can be seen from the function of the modern masjids, which do not portray the role of sustainability to facilitate the development of the surrounding community. Modern masjids are treated as iconic buildings, which much emphasis on aesthetics rather than functionality. Malay vernacular architecture formulated its character to the culture and environment. Nowadays, some designers adapt these components in the formation of contemporary architectural language. How does the vernacular and modern Malay masjids compare when it comes to the implementation of traditional Malay architecture in its design? Furthermore, modern designs of masjids rely more on the mechanical system for thermal comfort and thus, increasing the energy consumption. According to Chan (2004) and Singh (2006), $44.23 \%-64 \%$ of the annual electricity consumption in a building is allocated for the operations of air conditioners and other interior cooling mechanisms. This large consumption of energy for cooling stems from the problem of designing buildings that are ill adapted to the Malaysian local climate. This paper is aimed to identify which traditional vernacular architecture strategies are suitable to be adapted in modern masjids. The evidence compiled through observation in case studies captured an understanding of the effectiveness of environmental context in Malay vernacular architecture that can be adapted in contemporary quality of style.

\section{RESEARCH BACKGROUND}

\section{Malay Vernacular Masjid}

Malay vernacular architecture can be defined as a house designed to meet the thermal comfort of the occupant with consideration being given to climatic factors by using local materials and that reflect the social background of the occupant in the specific region. Abdul Ghaffar Ahmad (1999) mentioned that there are two types of architectural styles under the vernacular masjid category, 
Siti Salwana Mohd Nawayai, Zuraini Denan \& Noor Hanita Abdul Majid

Re-Adaptation of Malay Vernacular Architecture for Indoor Thermal Comfort in Modern Masjids Towards a Sustainable Design

namely traditional and regional influences that can be differentiated by the design of the roof. The traditional masjid is generally a long shape gable roof while the two or three tiered roofs can distinguish the regional influence. Examples of the vernacular masjids with traditional influence are Kampung Laut Masjid, Nilam Puri, Kelantan (1730's), Langgar Masjid, Kota Bharu, Kelantan (1871), Paloh Masjid, Ipoh, Perak (1912) and Kampung Raja Masjid, Seremban, Negeri Sembilan (1924). Examples of the vernacular masjids with regional influence are Tengkera Masjid, Melaka (1728), Kampung Keling Masjid, Melaka (1748), Old Masjid of Kampung Masjid Tinggi, Bagan Serai, Perak (1929) and Tanjung Keling Masjid, Melaka (1930).

\section{Sustainable Design in Built Environment}

Understanding thermal comfort is important to architecture. It not only lays the foundation for building designs but also relatively affects the achievement of a sustainable design. Julia (1997) supported contemporary models of thermal comfort recommendation that a narrow temperature range to be applied equally across all building types, climatic zones and populations. This method casts the building occupants as passive recipients of thermal applications which lead to thermal comfort standards that require energy-intensive environmental control strategies. On the other hand, sustainability applies to actions/developments that preserve the global environment and its non-renewable resources for present and future generations. Besides that, the sustainable system adapts local climatic context into the building, accounting for both temperature and humidity. It is about making the most of local conditions to make the building comfortable, affordable and sustainable.

\section{Thermal Comfort in the Malay Vernacular Masjid and Its Relationship to Climate}

Before the development of mechanical air conditioning systems, societies used cooling methods such as shading, thermal mass and natural ventilation to achieve thermal comfort. For example, the local climate has a direct influence on the formation of Malay vernacular architecture resulting in the masjid appropriately responding to environmental factors. The openings such as windows, panels and grills are an important feature of ventilation, which give relief to thermal discomfort. Void versus mass with the ground and verticality of Malay vernacular architecture provides adequate cross horizontal and vertical ventilation (Yuan, 1987). The overhang reduces the sun's glare and the direct sunlight coming into the building. The roof geometry plane of a Malay vernacular masjid is observed to be another distinctive feature with the environmental factors. The slop gable roof pitched would runoff water so quickly and allowed the air ventilated through the space below (attic space). The roof construction is usually left exposed with (C) 2020 by MIP 
PLANNING MALAYSIA

Journal of the Malaysia Institute of Planners (2020)

the lightweight thatch materials, which is tied to the wood spine to the roof construction members (Yuan, 1987). Overall, thermal comfort in Malay vernacular masjids is identified by comparing four major factors including architectural qualities, construction system, structural building components and non-structural building components.

\section{Architectural Qualities}

Among the architectural qualities, elements significantly considered are building shape/form, roof form, orientation, building envelope and surrounding context. The shape of the building plays a key role in the external surface area, which consequently determines its energy balance and hence, the cooling load. Examples of some building features, which were built in response to the warm and humid climatic conditions, are pitched roofs to enable rainwater to run off quickly and stilts to raise the masjids above ground level to avoid floods. Building orientation can also reduce cooling loads through minimizing solar heat gain through windows as well as minimizing or increasing solar heat gain through walls and roofs based on the climate. St. Clair (2009) mentioned that choosing an appropriate orientation relative to the wind direction can also help to maximize cross ventilation, which mostly suits buildings in hot and humid areas.

\section{Construction System}

The Malay vernacular architecture prefers to use materials that are easily available for a cost-saving approach. Nowadays, material such as concrete is considered easily available and not that costly compared to timber or steel. The Negeri Sembilan State masjid (refer Table 1) uses a series of intersecting reinforced concrete conoid to refer to the horn-like gable roofs of the Minangkabau traditional architecture. The reference to the 'bumbung gonjong' is uniquely expressed in the structural play of the conoids. The architect had not resorted to the simplistic revivalism alternative of the traditional roof but has reinterpreted it in an abstract but creative way. The gentle curve of the roof means that it does not require massive support, which allows for a completely free space below for the praying hall. Lace-like walls allow the hall to be freely cross ventilated by the natural breeze. This imitates the openness in the traditional vernacular masjid in maximizing airflow for thermal comfort. Furthermore, since the walls are not load bearing, they are perforated with carvings, similar to what can be seen in Malay traditional houses. 
Siti Salwana Mohd Nawayai, Zuraini Denan \& Noor Hanita Abdul Majid

Re-Adaptation of Malay Vernacular Architecture for Indoor Thermal Comfort in Modern Masjids Towards a Sustainable Design

\section{Structural Components}

The Roof space in Malay vernacular houses is properly ventilated by the provision of ventilation joints and panels in the roof construction. Figure 1 below shows the roof's opening on both sides to allow air movement into the house (Hanafi, 1994). As one of the indigenous materials, the attap roof used in Malay houses has a low thermal capacity. This material does not retain heat and cools immediately.

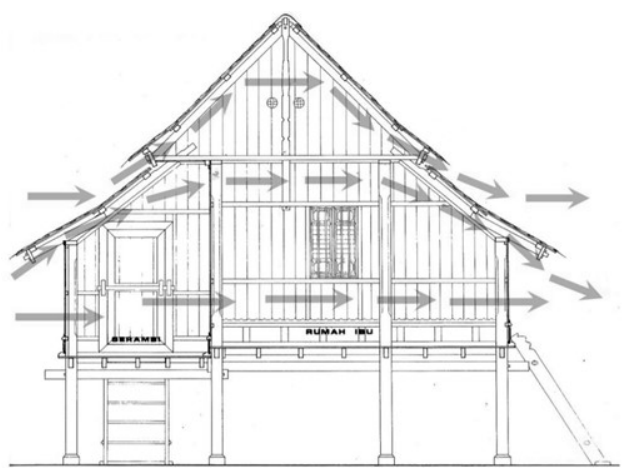

Figure 1: Ventilation Openings in the Roof of Traditional Malay House Source: Center of Built in the Malay World (KALAM), 1986.

Vernacular Malay architecture also uses prefabricated construction methods where all the components are made and assembled on-site, which allows the house to be dismantled and reassembled elsewhere in different locations. This can be translated as a sustainable approach adopted by the previous builders involved in Malay vernacular building forms.

\section{Non-Structural Components}

Like the Malay houses, the vernacular masjids portray a high level of craftsmanship. This can be seen in the non-structural components such as louvered windows, fanlights, carving wall panels and fascia boards for the floors, walls, stairs, and roofs that are fitted between the frames to allow natural cross ventilation of air. Window components can be divided into three operable sections; the top, middle and bottom. The top section, called ornamentation, is the fixed ventilation panel that is usually well decorated and carved. A Malay vernacular masjid also allows ventilation by having many full-length windows and doors at body level. Hassan and Ramli (2010) concluded that a large number of windows and openings aided by ornamentation at the perimeter walls can contribute to the cross-ventilation process (Figure 2). 


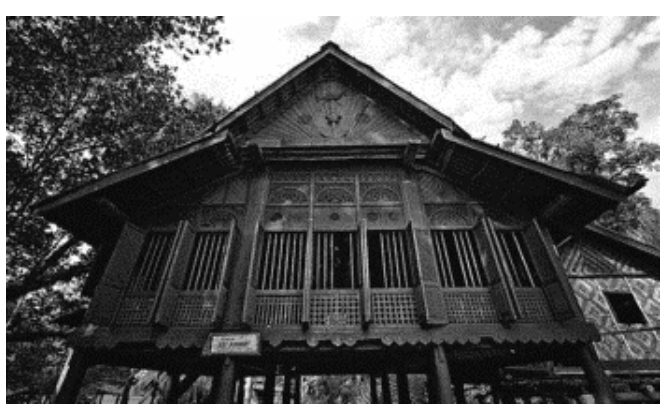

Figure 2: The Non-Structural Components of Traditional Malay House similar to Vernacular Masjid building facade Source: Hassan and Ramli (2010)

\section{ANALYSIS AND FINDINGS \\ Thermal Comfort in Modern Masjid Buildings and Energy Consumption}

Seven case studies have been conducted for this research. Table 1 indicates comparison on traditional and modern masjids when it comes to the implementation of Malay vernacular architecture as their design concept. Four key aspects of these case studies are compared to establish common features and differences between selected traditional Malay vernacular masjids and modern masjids with the same design concept in Malaysia. Observations were recorded and placed into these four key aspects namely architectural qualities, construction system, structural building components and non-structural building components. Findings from observations conducted concludes that application of Malay vernacular architectural concept in modern masjid case studies have changed gradually in parallel with the development of structural advances and construction methods. In comparison with thermal comfort in the traditional Malay vernacular masjids, modern masjids architectural form, space, construction systems and building materials in these case studies have evolved and developed to a greater extent. The development in materials and environmental control systems (e.g. air conditioning) has greatly influenced the modern masjid architecture. Concrete, bricks, steel, stone and marble are commonly used in the construction of modern masjids.

Primary data collected from observation of case studies recorded in Table 1 shows Masjid Kampung Laut as one of traditional timber masjid in Malaysia that were built according to construction and structural technology of that period. Therefore, modern Malay vernacular masjids are built according to the construction technology present at this time. The State Masjid of Negeri Sembilan is the building that truly practiced the metaphor of traditional form and state of the art for Negeri Sembilan. The designer adapted the concept of Malay vernacular design by designing a cantilevered platform that reaches out to the 
Siti Salwana Mohd Nawayai, Zuraini Denan \& Noor Hanita Abdul Majid

Re-Adaptation of Malay Vernacular Architecture for Indoor Thermal Comfort in Modern Masjids Towards a Sustainable Design

sun, bringing light into the interior space and allowing the hall to be naturally lit. Lace-like walls also allow the hall to be freely cross ventilated by natural breezes from the adjacent park and lake. At the same time, a series of intersecting reinforced concrete structures, the molded concrete underside the roof and pillars supporting a parasol roof made of a hyperbolic concave concrete shell seemed to be suitable building materials at that moment.

In an aspect of design context, Masjid Negara does not suggest any foreign influence but is uniquely suited within Malaysia's socio-cultural context. It also reflects a modern interpretation of Malay vernacular architecture and Islamic architecture. The use of a folded plate dome rejects any form of the colonial dome style. To provide sufficient daylight and passive cooling to the building, the architect designed an extensive set of serambi with light courts and air wells. It was also built on a raised platform on polotti with high ceilings and large fenestration for ventilation. Therefore, Masjid Negara is a good example of a modern masjid that is not only imbued with technological and spiritual qualities but is a modern masjid that preserves the spirit of true Malay vernacular architecture as well. It can also be concluded that the National Masjid has the closest criteria in terms of Malay vernacular architecture. The quantity of openness reflects the importance given to ventilation in the design of Malay vernacular architecture. The structure with minimal partitions in the interior will allow easy passage of air and cross ventilation. Its large roof and low windows tend to be under lighted. This gives a physiological effect of coolness as strong light is often mentally associated with heat. Indirect sources of light are the best forms of natural lighting for this climate as they minimize heat gain and glare. Direct sunlight should not be used for daylighting as it is accompanied by thermal radiation. These are the most effective means for climatic comfort in a building for the Malaysian climate and environment. This intelligent design of Malay vernacular architecture shows concern of thermal comfort for the occupants.

Based on the findings stated in Table 1, Tuanku Mizan Zainal Abidin Masjid is one of the early sustainable masjids in Malaysia. To become a sustainable building, the masjid should be providing a comfortable environment in the internal spaces. A unique cooling system was created by using a high-end technology system, which uses GKD's Escale stainless steel mesh that allows full natural air conditioning in the interior spaces. Furthermore, by using this highend technology, it also allows good daylight and gives the effect of transparency to the masjid thus reducing and saving energy usage. 
Table 1: Criteria of Malay Vernacular Masjids

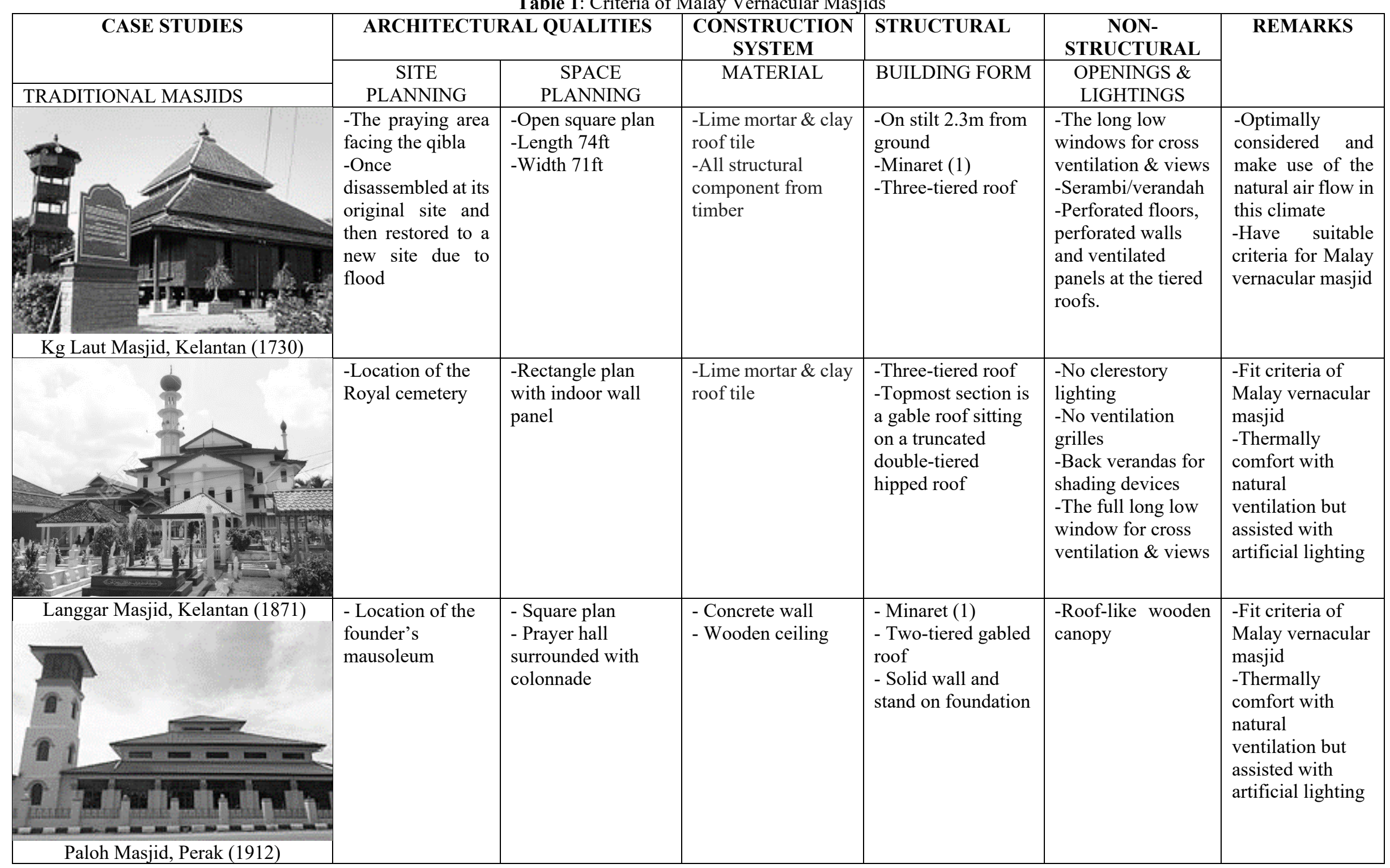


Siti Salwana Mohd Nawayai, Zuraini Denan \& Noor Hanita Abdul Majid

Re-Adaptation of Malay Vernacular Architecture for Indoor Thermal Comfort in Modern Masjids Towards a Sustainable Design

\begin{tabular}{|c|c|c|c|c|c|c|}
\hline \multicolumn{7}{|l|}{ MODERN MASJIDS } \\
\hline $\begin{array}{c}\text { National Masjid Kuala Lumpur } \\
(1965)\end{array}$ & $\begin{array}{l}\text {-Reflecting pools } \\
\text { and fountains } \\
\text { spread throughout } \\
\text { the compound to } \\
\text { cool down the } \\
\text { surrounding } \\
\text { throughout the } \\
\text { climate } \\
\text {-Prayer hall facing } \\
\text { Qibla }\end{array}$ & $\begin{array}{l}\text {-Folded plates of } \\
\text { the concrete main } \\
\text { roof are a solution } \\
\text { to achieving the } \\
\text { larger spans } \\
\text { required in the main } \\
\text { gathering hall. } \\
\text {-Relationship of } \\
\text { pathway and spaces } \\
\text { is "pass by spaces" }\end{array}$ & $\begin{array}{l}\text {-Concrete dome } \\
\text { with stained glass } \\
\text { for sustainability \& } \\
\text { lighting control. } \\
\text {-RC construction } \\
\text {-Marble floor \& } \\
\text { walls } \\
\text {-Column overlaid } \\
\text { with unglazed black } \\
\text { mosaic tiles at top } \\
\text { and base. } \\
\text {-Bottom of pillars at } \\
\text { prayer hall are } \\
\text { paved with terrazzo } \\
\text { \& concrete } \\
\text {-Verandah floor are } \\
\text { layered with black } \\
\text { terrazzo tiles for } \\
\text { low maintenance \& } \\
\text { sustainability } \\
\end{array}$ & $\begin{array}{l}\text {-Minaret (1) } \\
\text {-The main roof is } \\
\text { reminiscent of an } \\
\text { open umbrella } \\
\text {-Star dome } \\
\text { represent the } 13 \\
\text { states of Malaysia } \\
\text { and five pillars of } \\
\text { Islam. } \\
\text {-Post and beam } \\
\text { concrete structure } \\
\text {-Built on raised } \\
\text { platform with high } \\
\text { ceilings }\end{array}$ & $\begin{array}{l}\text {-Serambi and } \\
\text { verandah with light } \\
\text { courts \& air wells } \\
\text { for sufficient } \\
\text { daylight \& passive } \\
\text { cooling } \\
\text {-Contemporary } \\
\text { expression } \\
\text { calligraphy and } \\
\text { ornamentation for } \\
\text { aesthetic and } \\
\text { ventilation } \\
\text {-Natural lighting } \\
\text { from roof onto } \\
\text { column and floor } \\
\text {-façade from plain } \\
\text { white concrete to } \\
\text { create light \& } \\
\text { shadow effect }\end{array}$ & $\begin{array}{l}\text {-Optimally } \\
\text { considered and } \\
\text { make use of the } \\
\text { natural air flow in } \\
\text { this tropical } \\
\text { climate } \\
\text {-Have suitable } \\
\text { criteria for } \\
\text { vernacular } \\
\text { architecture }\end{array}$ \\
\hline State Masjid Negeri Sembilan (1970) & $\begin{array}{l}\text { Adjacent to park } \\
\text { and lake. }\end{array}$ & $\begin{array}{l}\text {-A nine-sided } \\
\text { polygon with a } \\
\text { large open } \\
\text { polygonal prayer } \\
\text { space. } \\
\text {-The double-storey } \\
\text { volume prayer hall } \\
\text { has a ring of first } \\
\text { floor terraces } \\
\text { supported by nine } \\
\text { conical buttresses } \\
\text { rising from ground } \\
\text { level. }\end{array}$ & $\begin{array}{l}\text {-Glass and timber at } \\
\text { façade building } \\
\text {-Series of } \\
\text { intersecting } \\
\text { reinforced concrete } \\
\text {-Pillar supporting a } \\
\text { parasol roof made } \\
\text { of a hyperbolic } \\
\text { concave concrete } \\
\text { shell. } \\
\text {-Molded concrete } \\
\text { underside the roof }\end{array}$ & $\begin{array}{l}\text {-Minaret (1) } \\
\text {-The horn-like } \\
\text { gable roofs of the } \\
\text { traditional } \\
\text { Minangkabau. } \\
\text {-Curves and lines of } \\
\text { gently moving } \\
\text { upward to a point } \\
\text { underside of the } \\
\text { roof } \\
\text {-The non load- } \\
\text { bearing wall are } \\
\text { perforated with } \\
\text { carvings }\end{array}$ & $\begin{array}{l}\text {-The curve of the } \\
\text { roof allowing a } \\
\text { completely free } \\
\text { space below for the } \\
\text { praying hall. } \\
\text {-Cantilevered } \\
\text { platforms reach out } \\
\text { to the sun, bringing } \\
\text { light to the interior } \\
\text { space, allowing the } \\
\text { hall to be naturally } \\
\text { lit. } \\
\text {-Lace-like walls } \\
\text { allow the hall to be } \\
\text { freely cross- } \\
\text { ventilated by } \\
\text { breezes. }\end{array}$ & $\begin{array}{l}\text {-Design } \\
\text { consideration } \\
\text { highlighted on the } \\
\text { traditional } \\
\text { Minangkabau } \\
\text { architecture } \\
\text {-Optimally } \\
\text { considered and } \\
\text { make use of the } \\
\text { natural air flow } \\
\text { and lighting in } \\
\text { tropical climate }\end{array}$ \\
\hline
\end{tabular}


PLANNING MALAYSIA

\begin{tabular}{|c|c|c|c|c|c|c|}
\hline$\underset{\substack{\text { Tuanku Mizan Zainal Abidin Masjid } \\
\text { (2004) }}}{2}$ & $\begin{array}{l}\text {-Adjacent to } \\
\text { landscape and } \\
\text { lake. } \\
\text {-Adjacent to the } \\
\text { main prayer room } \\
\text { is surrounded by a } \\
\text { pool to make } \\
\text { guests enjoy a } \\
\text { cool and airy } \\
\text { atmosphere. }\end{array}$ & $\begin{array}{l}\text {-The main prayer } \\
\text { hall is surrounded } \\
\text { by marshrabiyah } \\
\text { screen consisting of } \\
\text { lattice and } \\
\text { architectural } \\
\text { metallic wailing } \\
\text { screen which serves } \\
\text { as transparent light } \\
\text { and wind }\end{array}$ & $\begin{array}{l}-70 \% \text { steel \& } 30 \% \\
\text { concrete } \\
\text {-The main entrance } \\
\text { is strengthened with } \\
\text { glass reinforced } \\
\text { concrete to increase } \\
\text { the integrity of the } \\
\text { structure and uses } \\
\text { fine glass to create } \\
\text { an illusion of a } \\
\text { white masjid from } \\
\text { afar. }\end{array}$ & $\begin{array}{l}\text {-characterise three } \\
\text { design principles: } \\
\text { simplicity, airiness } \\
\text { and transparency. } \\
\text {-The edges of the } \\
\text { masjid's roof are } \\
\text { able to shelter the } \\
\text { people praying } \\
\text { outside of the main } \\
\text { prayer hall from } \\
\text { rain }\end{array}$ & $\begin{array}{l}\text {-Gas District } \\
\text { Cooling" AC } \\
\text { technology } \\
\text {-Natural ventilated } \\
\& \text { fans stainless } \\
\text { steel mesh for } \\
\text { atmospheric } \\
\text { quality. } \\
\text {-Semi-transparent } \\
\text { spiral mesh } \\
\text { provides reliable } \\
\text { protection from the } \\
\text { sun and rain. }\end{array}$ & $\begin{array}{l}\text {-Optimal use of } \\
\text { the natural air } \\
\text { flow and lighting } \\
\text {-Suitable criteria } \\
\text { of Malay } \\
\text { vernacular } \\
\text { architecture with } \\
\text { modern } \\
\text { technology } \\
\text {-Sustainable } \\
\text { masjid }\end{array}$ \\
\hline 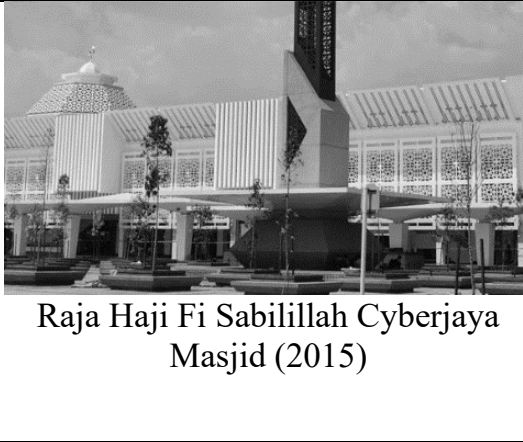 & $\begin{array}{l}\text { Grasscrete paving } \\
\text { system on the car } \\
\text { park area }\end{array}$ & $\begin{array}{c}\text { Rainwater } \\
\text { harvesting for } \\
\text { landscaping and } \\
\text { toilet use. }\end{array}$ & & $\begin{array}{l}\text { Rooftop solar } \\
\text { panels }\end{array}$ & $\begin{array}{l}\text {-Variable } \\
\text { Refrigerant Flow } \\
\text { (VRF) AC system } \\
\text { for energy saving. } \\
\text {-Energy-efficient } \\
\text { LED lights. } \\
\text {-Low-E panel glass } \\
\text { that reduces heat } \\
\text { transfer. } \\
\text {-Max natural air } \\
\text { ventilation system. }\end{array}$ & $\begin{array}{l}\text {-optimally } \\
\text { considered and } \\
\text { make use of the } \\
\text { natural air flow } \\
\text { and lighting in } \\
\text { tropical climate } \\
\text {-Green masjid }\end{array}$ \\
\hline
\end{tabular}


Siti Salwana Mohd Nawayai, Zuraini Denan \& Noor Hanita Abdul Majid

Re-Adaptation of Malay Vernacular Architecture for Indoor Thermal Comfort in Modern Masjids Towards a Sustainable Design

At the same time, the design of Raja Haji Fi Sabilillah Cyberjaya Masjid is an inspiration for more developments of green masjids in the future. It is the first masjid in Malaysia to be awarded a Platinum - Green Building Index. The main design intent of this masjid is to save energy through its design by having an average daytime temperature of $26^{\circ} \mathrm{C}$ to achieve a thermal comfort zone. Some of this green building features of the masjid include rainwater harvesting for landscaping and toilet use, Variable Refrigerant Flow (VRF) air conditioning system for energy saving, energy efficient light-emitting diodes (LED) lights, low e-panel glass that reduces heat transfer, grasscrete paving system for the car park area, rooftop solar panels and maximum natural air ventilation system.

\section{CONCLUSION}

Masjids represent a great place of importance and function for Muslims communities. The feeling of tranquility and peace is what worshippers are looking for in masjids but to attain this, they need to feel thermally comfortable and relaxed inside the masjids. In response to the seriousness of working toward a sustainable future and the identity of local masjids, the government, organizations, and agencies have been developing policies, laws, regulations and building codes. The goals of these initiatives are to improve the wellbeing of people and to value the natural environment. For architects to successfully apply the principles of sustainable design, there is a requirement to understand the laws and regulations related to the environment. Moreover, there is a need to be more proactive and take responsibility without solely relying on the legislative enforcement only. Designers need to question the impact of each decision they make when designing a building and adopt a long-term view by focusing on sustainability rather than the aesthetical building form. This paper recommends that new masjid designs should move towards adaptation and interpretation of vernacular architecture whilst being suited with the contemporary context and technology. Malay vernacular identity in any modern designed buildings especially masjids can be considered as a challenging task in architecture. However, referring to climatic characteristics and elements of thermal comfort in Malay vernacular masjid, modern building designs in Malaysia should be able to optimize thermal comfort by fulfilling all these major factors. This paper represents key aspects of the most suitable traditional vernacular architecture strategies to be adapted in modern masjids namely architectural qualities, construction system, structural building components and non-structural building components. If a modern masjid is designed and built by considering the above points, it can result in a very appropriate modern building form suited specifically to the vagaries of tropical climate in Malaysia. 


\section{REFERENCES}

Abdul Ghafar Ahmad (1999). The Architectural Styles of Mosque in Malaysia: From Vernacular To Modern Structures. Proceedings of the Symposium on Mosque Architecture: The Historic and Urban Developments of Mosque Architecture, Vol. 2, 70-77.

Baharudin, N. A. (2016). Architectural Style of Da'wah Mosque in Malaysia: from Vernacular to Modern Structure. International Journal of Built Environment and Sustainability. EISSN 2289-8948.

Center of Built in the Malay World (KALAM), (1986). Rumah Datuk Baginda Tan Mas Mohar (1850). Universiti Teknologi Malaysia.

Chan, S. A. (2004) Energy Efficiency: Designing Low Energy Buildings Using Energy 10. CPD Seminar 7th August 2004. Malaysia: Pertubuhan Arkitek Malaysia.

Hanafi, Z. (1994). Housing Design in Relation to Environmetal Comfort - A Comparison of the Traditional Malay House and Modern Housing. Building Research and Information, Volume 22.

Hassan, A. S., \& Ramli, M. (2010). Natural Ventilation of Indoor Air Temperature: A Case Study of the Traditional Malay House in Penang. Science Publications, American J. of Engineering and Applied Science 3.

Hassan, A. S. \& Ahmad Nawawi, M. S. (2014). Malay Architectural Heritage on Timber Construction Technique of The Traditional Kampung Laut Old Mosque, Malaysia. Asian Social Science, Vol. 10 (8), 230-240.

Julia, R. (1997). Thermal Comfort: Designing for People. Center for Sustainable Development, School of Architecture, University of Texas, Austin.

Peter O. Akadiri, Ezekiel A. Chinyio \& Paul O. Olomolaiye (2012). Design of A Sustainable Building: A Conceptual Framework for Implementing Sustainability in the Building Sector. Buildings 2012, vol. 2, 126-152. DOI:10.3390/buildings2020126 ISSN 2075-5309.

Singh, G. (2006). Household Energy Use by CETDEM. Malaysia: Centre for Environment, Technology and Development.

St. Clair, P., (2009). Low-Energy Design in the United Arab Emirates - Building Principles. BEDP Environment Design Guide, February Issue, 1-10.

Yuan, L. J. (1987). The Malay House: Rediscovering Malaysia"s Indigenous Shelter System. Kuala Lumpur: Institut Masyarakat.

Received: January 2020. Accepted: $1^{\text {st }}$ April 2020 